\title{
拘束空間におけるインピーダンス制御の安定化を実現する 動特性調節器の設計・開発*
}

\author{
入野 功輔*1, 積際 徹*2, 横川 隆一 ${ }^{* 2}$ \\ Development of Mechanical Regulator of Physical Human-Robot Interaction \\ to Stabilize the Impedance Control in a Constraint State
}

\author{
Kosuke IRINO*1, Toru TSUMUGIWA and Ryuichi YOKOGAWA \\ ${ }^{* 1}$ Doshisha Univ. Dept. of Biomedical Engineering \\ Tatara-miyakodani 1-3, Kyotanabe-city, Kyoto, 610-0321 Japan
}

\begin{abstract}
The purpose of this paper is to develop a mechanical regulator and a robot motion control scheme for a human-robot cooperative task in stiff environment. The proposed mechanical regulator realizes the stable motion of the robot in the stiff environment by regulating dynamical interference between human dynamics and robot dynamics. The proposed mechanical regulator is composed of following components: (i) the motion-detecting system that detects relative positional deflection data between the human motion and the robot motion; (ii) the mechanical load regulating device that regulates an operational load of the robot motion for the human; (iii) the mechanical gravity canceller that reduces a dead load with the mechanical regulator when an operator manipulates the mechanical regulator. In addition, a switching control scheme of impedance parameters is proposed to realize the human-robot cooperative task in the stiff environment. To confirm the effectiveness of the proposed mechanical regulator and the proposed switching control scheme, experiments of the human-robot cooperative task in the constraint state are carried out. The experimental results show that the proposed mechanical regulator and the proposed switching control scheme are effective for the human-robot cooperation in the constraint state.
\end{abstract}

Key Words : Human-Robot-Interaction, Robot, Man-Machine System, Contact Stability Problem, Motion Control, Impedance Control

\section{1. 緒言}

人間とロボットが力学的に協調する環境におけるロボットの運動制御法としてインピーダンス制御が広く用い られている(1) (9). インピーダンス制御は操作者および作業対象物（以下，操作者および作業対象物を統合して操 作者とする）とロボットが剛に結合されているため，ロボット手先に与えるインピーダンス特性（剛性・粘性・ 慣性）が操作者の動特性に干渉寸る. そのため, 高剛性の環境とロボットが接触する場合, ロボットの制御が不 安定になるという接触安定問題が知られている(10) (14). この問題を解決するために, (i)ロボット手先に与える粘性 を大きくする方法 ${ }^{(15)}$, (ii) 外部環境と接触した際に, 操作力による指令速度を接触力による指令速度が超えた場合, システムが不安定になることを回避するようにロボットに与える指令速度を修正する方法 ${ }^{(16)}$, (iii)環境との相互 作用力に上限を設定する方法 ${ }^{(17)}$ などが提案された．しかし，これらには，(i)粘性を大きくすることで操作者に加 わる負担が大きくなる, (ii)ロボットへの指令速度を修正するため, 操作者には不安定な運動をしないように制御 されたロボットの動特性のみが伝わり, 操作者と外部環境の力学的関係がなくなるため, 外部環境の動特性に則 した操作ができない，(iii)接触する環境の岡性が既知でなければならないといった問題があった.

そこで, 本研究では, インピーダンス制御において, ロボットと操作者の動特性の互いの干渉具合を調節し,

* 原稿受付 2013 年 2 月 15 日

${ }^{* 1}$ 同志社大学大学院 生命医科学研究科

*2 正員, 同志社大学 生命医科学部 医工学科（广 $610-0321$ 京都府京田辺市多々羅都谷 1-3）

E-mail: ttsumugi@mail.doshisha.ac.jp 
それぞれの動特性を低干渉化（もしくは非干渉化）させる動特性調節器を開発する．そして，操作者がロボット に加える力に応じたインピーダンス制御と，操作者の動きにロボットが追従する制御を組み合わせた制御則を提 案することで, 高岡性環境との接触安定問題の解決を目的とする. 従来制御方法では操作者 (外部環境) とロボッ トの動特性が結合されており，インピーダンス特性に従った協調作業が行われていたが，干渉具合を調節するこ とで両者の動特性が独立した状態となり互いの影響が消失することから，制御の安定状態を保つことができる. このように提案手法では，機構的な低干渉化制御によってインピーダンス制御における接触安定問題を解決でき ることから, 先に従来制御法の問題として述べた (i) 制御の安定化を目的とした粘性の調整が不要になる.また, 低干渉化によってロボットと操作者 (外部環境) の間に生じる相互作用力が減少するために, (ii) ロボットの運 動として設定したインピーダンス特性に影響されることなく，操作者自身や外部環境の動特性に則した運動が可 能となり, 直感的な協調作業が実現できる. そして, 低干渉化の効果により操作者が直接的に外部環境を認識で きるようになることから，(iii) 接触対象となる環境の剛性が既知である必要がなくなる.

本研究では，まず，ロボットと操作者の動特性の干渉具合を減少させた時に生じる，両者間の相対的な位置偏 差を検出する位置偏差検出機構および両者間に発生する相互作用力を可変調節する力伝達量調節機構を開発する

(以下， 2 つの機構を合わせて調節器とする). 力伝達量調節機構の働きにより, 両者間に生じる力学的な干渉 状態を調節することができる，干渉状態の調節時には，操作者からロボットへ伝達される力覚情報および位置偏 差情報に仮想バネの剛性係数を乗じて生成される仮想力の両方を制御入力とし, 力覚情報に基づくインピーダン ス制御と操作者の動きにロボットが追従する制御を組み合わせた運動制御を行う。そして，高剛性環境との接触 を判別し，制御パラメータを自動で切替える制御（以下，自動切替え法とする）を提案する. 提案システムでは, 操作者の操作によって制御法を任意に切り替えることが可能であり, 作業内容や作業状況に応じて適切な干渉状 態や制御法を適用することができる.

提案システムと自動切替え法の有効性を示寸ため, 高剛性環境との接触を伴う人間とロボットの協調組立作業 を行い, 安定状態下で作業を遂行できることを示す.また, 提案システムで得られた結果をもとに従来のインピー ダンス制御との違いについて検討する. なお, 本研究では, 制御の簡単化のため, ロボットの運動は回転運動を 考慮せずに，並進 3 軸方向に限定する.

\section{2. 制御システムおよび提案調節器}

\section{$2 \cdot 1$ 制御システム}

本研究の制御システムおよび提案調節器の概要を図 1 に示す. 7 自由度を有するロボット（三菱重工業 PA-10） の先端に力覚センサ（ニッタ社 IFS-67 M25A 50-I40）が取り付けられており，その上に位置偏差検出機構および 力伝達量調節機構により構成された提案調節器が取り付けられている. 操作者は提案調節器の上部のハンドル部 に取り付けられた作業対象物を持ちロボットを操作する. 位置偏差検出装置はその時の作業対象物の位置(以下,

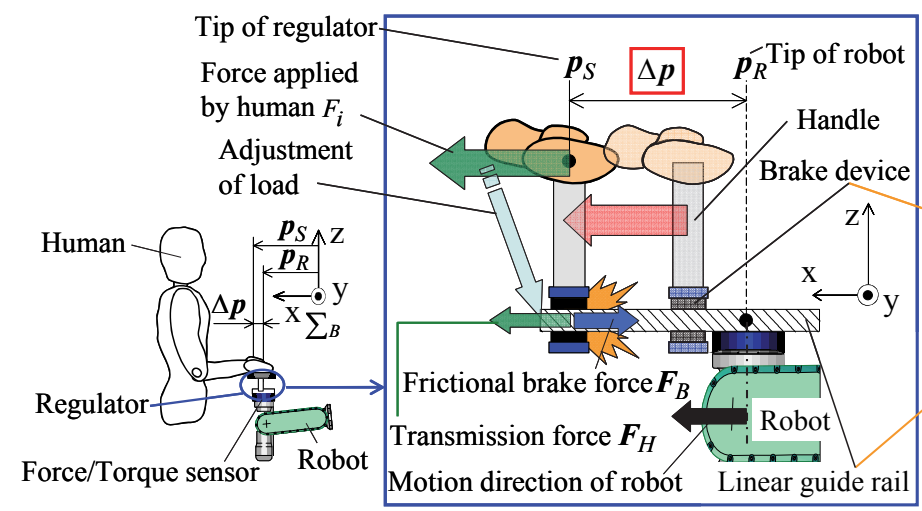

(i ) $\left|F_{i}\right| \leq$ frictional brake force $\rightarrow \quad F_{i}=F_{H}$

(ii ) $\left|F_{i}\right|>$ frictional brake force $\rightarrow \quad F_{i}>F_{H}$

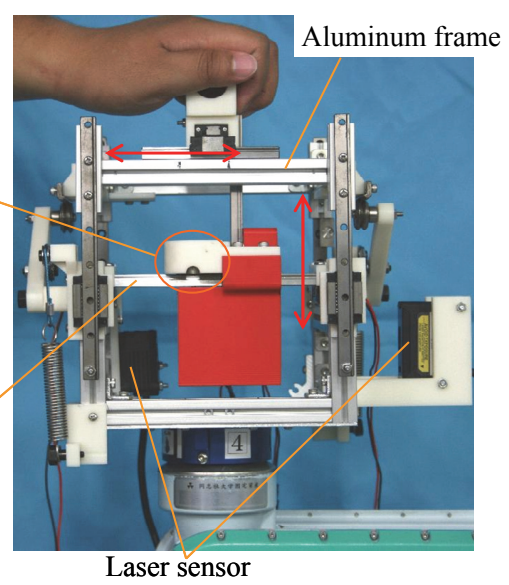

Laser sensor

Fig.1 Overview of proposed control system 
作業対象物の位置を操作者の手先位置とする） $\boldsymbol{p}_{S}=\left[p_{S x}, p_{S v}, p_{S z}\right]^{T}$ とロボットの先端位置 $\boldsymbol{p}_{R}=\left[p_{R x}, p_{R v}, p_{R z}\right]^{T}$ の間 に生じる位置偏差 $\Delta \boldsymbol{p}=\left[\Delta p_{x}, \Delta p_{y}, \Delta p_{z}\right]^{T}$ を検出する. 操作者からロボットに伝達される力 $\boldsymbol{F}_{H}=\left[F_{H x}, F_{H y}, F_{H z}\right]^{T}$ は力覚センサによって検出される. なお， $\boldsymbol{p}_{S}, \boldsymbol{p}_{R}, \Delta \boldsymbol{p}, \boldsymbol{F}_{H}$ はベクトルである. また, 位置偏差検出機構のリ ニアガイドレールに取り付けられた力伝達量調節機構が摩擦負荷を変化させ, 操作者とロボット間に生じる相互 作用力の大きさを調節し, 操作者からロボットに伝達される力 $\boldsymbol{F}_{H}$ の可変制御を行う. 提案調節器の外形寸法は 幅 $271 \times$ 奥行き $244 \times$ 高さ $192 \mathrm{~mm}$ ，質量は $2.6 \mathrm{~kg}$ である．なお，ロボットの制御のサンプリングタイムは $2 \mathrm{~ms}$ であ る.

\section{$2 \cdot 2$ 位置偏差検出機構}

図 2 に位置偏差検出機構の(a)概要と(b)外観を示寸. 図 2 に示すように力覚センサの上部に取り付け, 並進 3 軸 方向（x，y， z 軸）に設置したリニアガイドを用いた摺動部を持つ構造になっている.また， ロボット手先位 置と操作者間の手先位置の位置偏差情報 $\Delta \boldsymbol{p}$ の検出は, 上下方向（ $\mathrm{z}$ 軸）と水平方向（ $\mathrm{x}-\mathrm{y}$ 平面）に移動する八 ンドル部に設置されたレーザターゲット部の基準点 Q からの移動量をレーザセンサ（センサヘッド KEYENCE 社 IL-65，アンプユニット KEYENCE 社 IL-1000）により計測することで行う．図 2(b)はx， z 軸方向に機構の ハンドル部を動かした時の機構の動きを示している. 本機構は図 2, 図 3 中の並進 3 軸方向（ $\mathrm{x}, \mathrm{y}, \mathrm{z}$ 軸）に ついて $\pm 25 \mathrm{~mm}$ の検出範囲 (可動範囲) を有し, その範囲内の運動であれば位置偏差情報 $\Delta \boldsymbol{p}$ の検出が可能であ り, かつ, 操作者とロボットの動特性の干渉を消失させることができる.なお, レーザセンサの検出精度は $0.012 \mathrm{~mm}$, サンプリングタイムは $1 \mathrm{~ms}$ である.

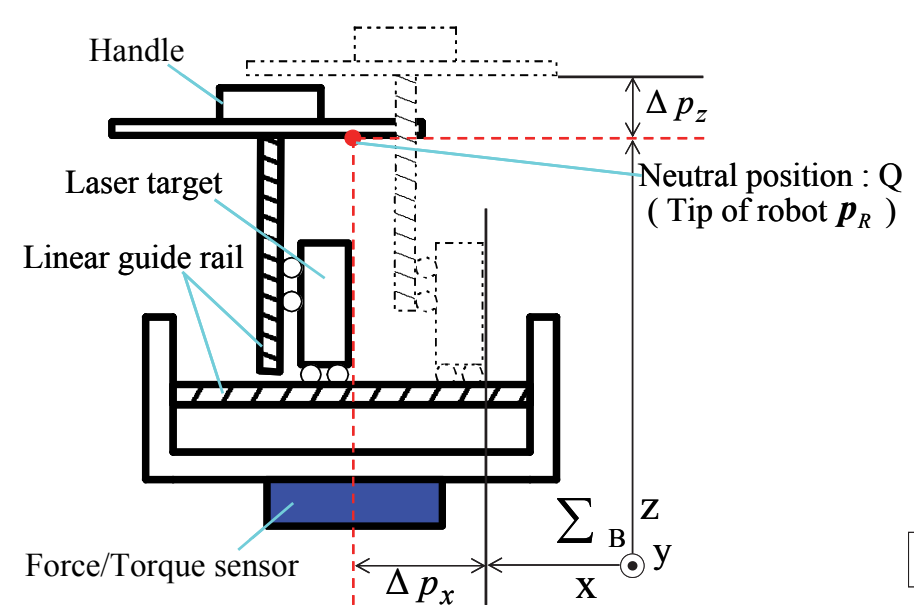

(a) Structure

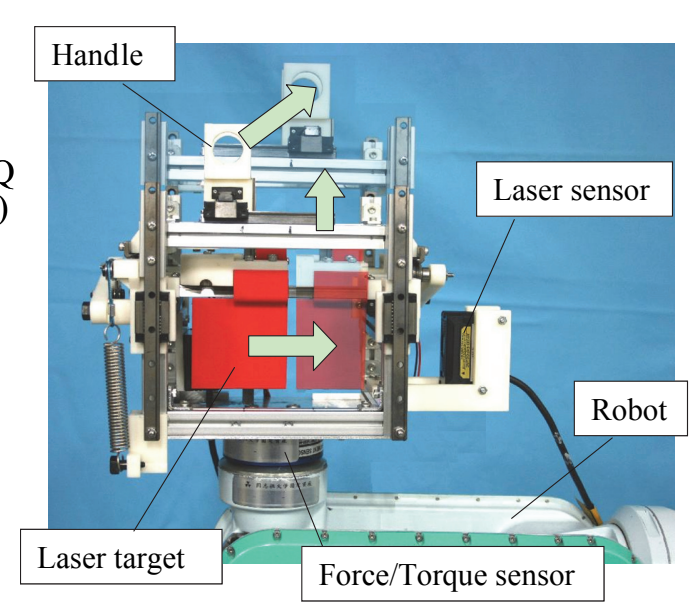

(b) Appearance

Fig.2 Structure of positional deflection detection device

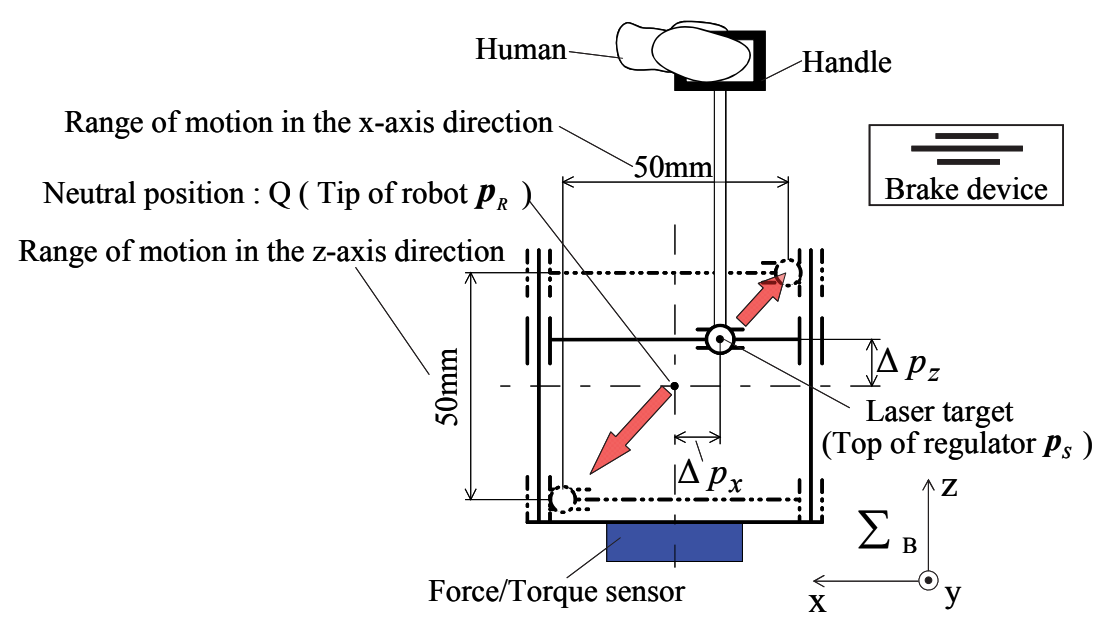

Fig.3 Measurable range of positional deflection detection device 


\section{$2 \cdot 3$ 力伝達量調節機構}

図 4 に力伝達量調節機構の(a)概要と(b)外観を示す. ロボットと操作者の動特性の非干渉化を行うと, 両者間に は相互作用力が生じず，操作者からロボットに力を伝達できない状態となる．そこで，位置偏差検出機構の摺動 部に摩擦負荷を与えることで相互作用力の大きさを可変調節し，操作者から提案調節器を介してロボットへと伝 わる力覚情報の量（以下これを力伝達量とする）を調節する力伝達量調節機構を開発した．位置偏差検出機構の リニアガイドと電磁石（ギガテコ社 TNM208S）を有するブレーキ力発生装置を取り付け，電磁石に入力する電 圧を調節することで摩擦力を制御し，ロボットへ伝達される力の大きさの調節を行う。なお，本機構では $2 \mathrm{~N} か$ ら $10 \mathrm{~N}$ の範囲で力伝達量を変化させることができる. 入力電圧と電磁石のブレーキ力の関係を図 5 に示す.

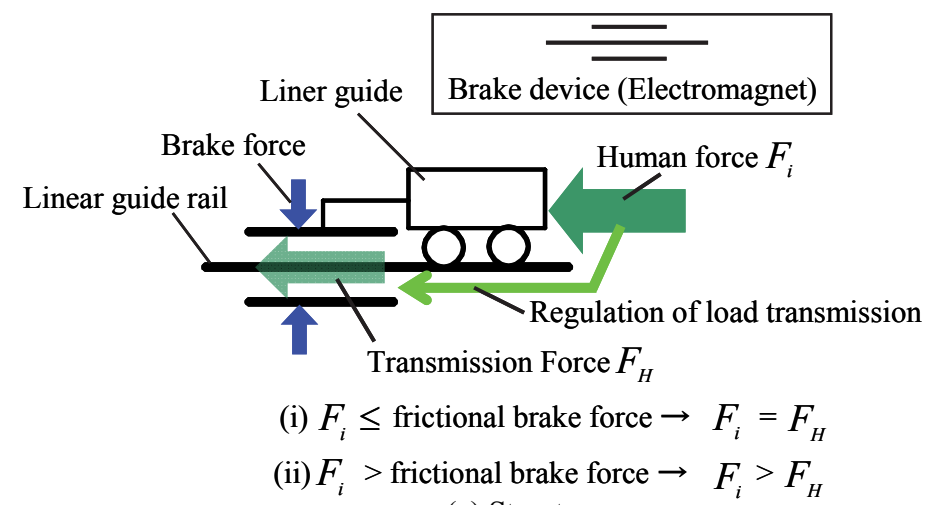

(a) Structure
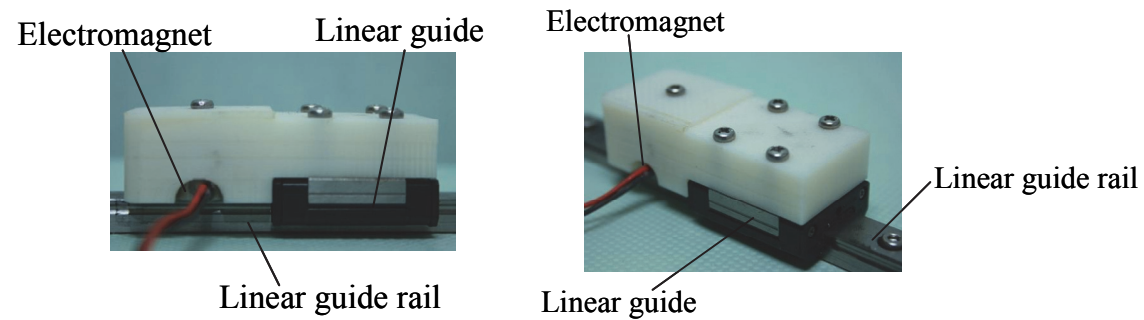

(b) Appearance

Fig.4 Load regulating device

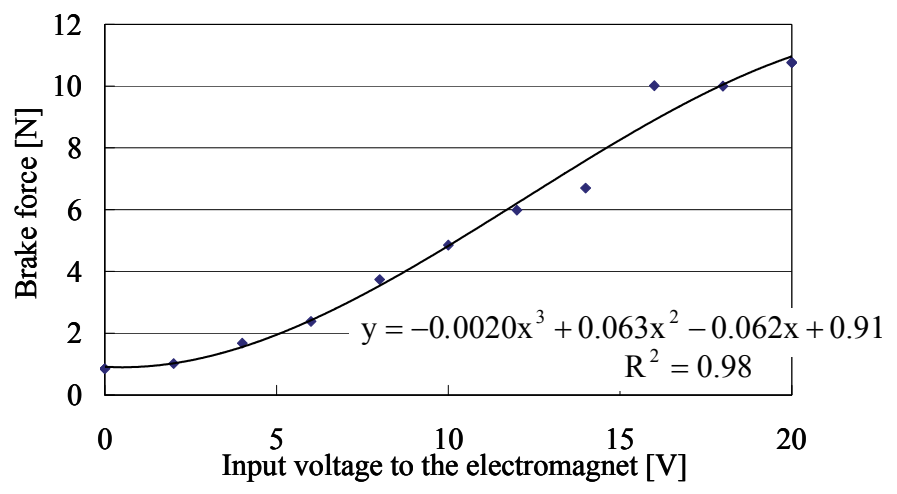

Fig.5 Relationship between brake force and input voltage to the electromagnet

\section{$2 \cdot 4$ 自重補償機構 ${ }^{(18) \sim(20)}$}

力伝達量調節機構への入力電圧が低い場合 (摩擦力が小さい場合), 図 2 のハンドル部は自重によって落下し, 操作者自身がその自重を補償しなくてはならず，操作性が悪化することが予想される．そこで，バネとリンクに よって構成される機構(18) (20)を利用して, ハンドル部の自重補償機構を導入した. 図 6 に外観を示寸. なお, 本

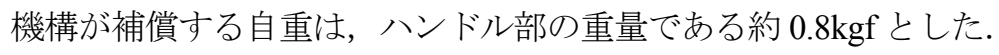




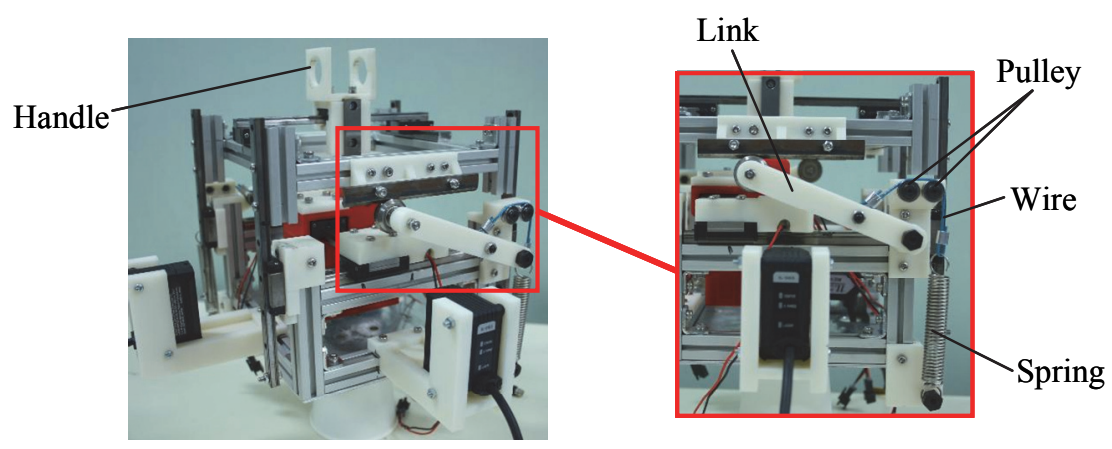

Fig.6 Appearance of mechanical gravity canceller of the proposed regulator

\section{3. ロボットの運動制御則}

力覚センサによって検出された力 $\boldsymbol{F}_{H}[\mathrm{~N}]$ と, 提案調節器によって検出された操作者とロボットの手先の位置偏 差情報 $\Delta \boldsymbol{p}[\mathrm{m}]$ に $3 \times 3$ 行列の仮想剛性係数 $\boldsymbol{K}_{V}[\mathrm{~N} / \mathrm{m}]$ を乗じた力を仮想力としてインピーダンスモデルに入力し, ロボットはこれらの入力が減少するように運動制御される. 本研究ではロボット手先の目標インピーダンスを次 式のように設定した.

$$
\boldsymbol{M}_{R} \ddot{\boldsymbol{p}}_{R}(\mathrm{t})+\boldsymbol{D}_{R} \dot{\boldsymbol{p}}_{R}(\mathrm{t})=\alpha \boldsymbol{K}_{V} \Delta \boldsymbol{p}(\boldsymbol{t})+(1-\alpha) \boldsymbol{F}_{H}(\mathrm{t})
$$

ここで， $\boldsymbol{p}_{R}$ はロボットの手先位置 $[\mathrm{m}]$ であり， $\dot{\boldsymbol{p}}_{R} ， \ddot{\boldsymbol{p}}_{R}$ は $\boldsymbol{p}_{R}$ の速度 $[\mathrm{m} / \mathrm{s}] ，$ 加速度 $\left[\mathrm{m} / \mathrm{s}^{2}\right]$ 表し， $\boldsymbol{M}_{R} ， \boldsymbol{D}_{R}$ はそれ ぞれ慣性係数 $[\mathrm{kg}]$, 粘性係数 $[\mathrm{Ns} / \mathrm{m}]$ を表す $3 \times 3$ 対角行列である. 制御のブロック線図を図 7 に示し, 図 8 に力学 モデルを示す.ここで， $\alpha$ は力覚情報と位置偏差情報の制御入力としての重み係数である. 図 9 に重み係数 $\alpha$ と 力伝達量調節機構のブレーキ力によって変化する制御則の違いを示す.

(i) $\alpha=0$ の場合

制御入力が力覚情報 $\boldsymbol{F}_{H}$ のみとなり, 力覚情報に基づくインピーダンス制御が実現される.このときの制御モ デルが図 9(a)である. また, 図 9(a)のように, 力伝達量調節機構のブレーキ力を最大にすることで操作者とロボッ 卜は力学的に結合され, 両者の間で生じる相互作用力がすべてロボットの制御入力となる. なお, 操作者とロボッ 卜は力学的に結合されているため, 両者の間には手先の位置偏差情報 $\Delta \boldsymbol{p}$ は発生しない.

(ii) $\alpha=1$ の場合

制御入力は位置偏差情報による仮想力 $\boldsymbol{K}_{V} \Delta \boldsymbol{p}$ のみであり，位置偏差情報 $\Delta \boldsymbol{p}$ を減少させるように操作者の手先 にロボットの運動が追従する制御となる。このときの制御モデルが図 9(b)である. 力伝達量調節機構のブレーキ 力を発生させないことで, 操作者とロボットは機構的に切り離される. このとき, 位置偏差検出機構の可動範囲 内で両者の動特性は非干渉化され. 力学的相互作用が消失した状態になることから，それぞれの動特性に従った 運動を実現できる.

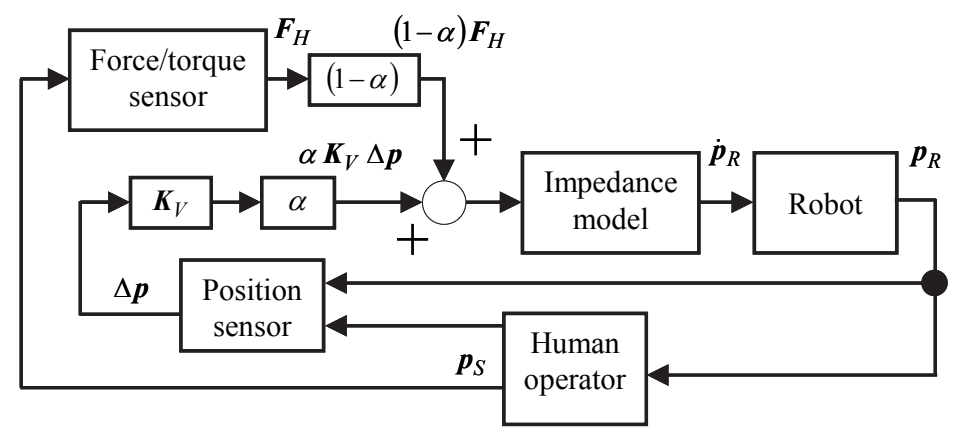

Fig.7 Block diagram of robot motion control 
(iii) $0<\alpha<1$ の場合

制御入力は力覚情報 $\boldsymbol{F}_{\mathrm{H}}$ と位置偏差情報による仮想力 $\boldsymbol{K}_{V} \Delta \boldsymbol{p}$ の両方であり, 上述の 2 つの状態の中間状態が実 現される. 重み係数 $\alpha$ と力伝達量調節機構のブレーキ力を調節することで, 2 つの制御入力の大きさと割合を調 節することができる.

上記の制御則において, 作業内容や作業状況に応じて適切な制御パラメータ（重み係数 $\alpha$ と力伝達量調節機構 のブレーキ力）を設定することで，安定状態下で協調作業を実現することができる．適用作業に関する最適な制 御パラメータの決定手法の確立については, 今後の検討課題の一つである.

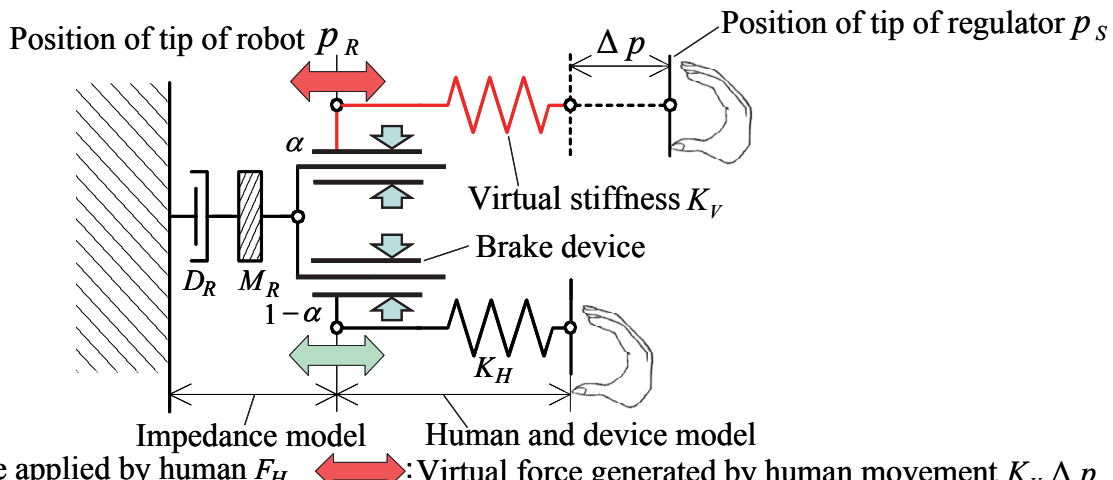

Fig.8 Dynamics model of robot motion control

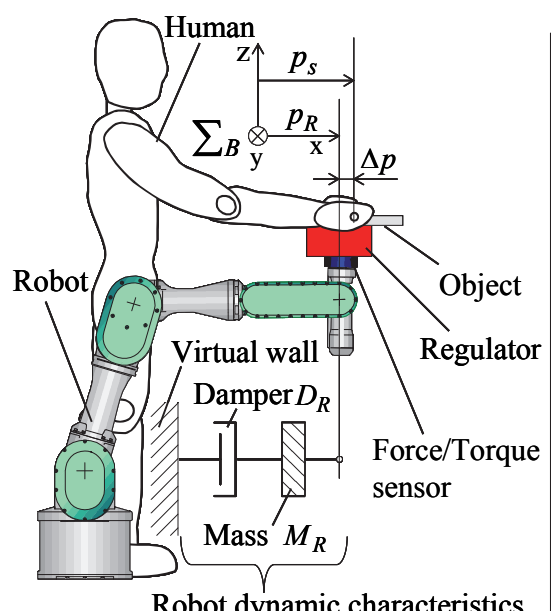

Robot dynamic characteristics

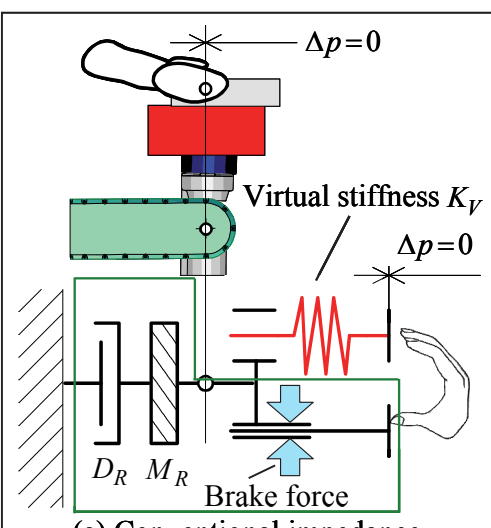

(a) Conventional impedance control type

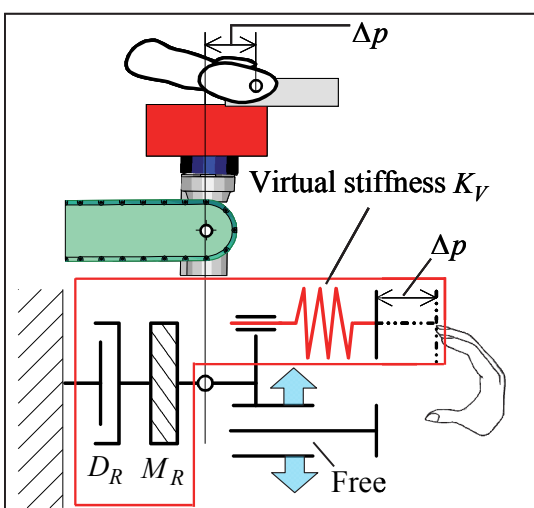

(b) Control type of non-interference between object dynamics and robot dynamics

Fig.9 Overview of robot motion control

\section{4. 自動切替え法の提案}

力覚情報と位置偏差情報をもとに運動制御則の制御パラメータと, 力伝達量調節機構の力伝達量を自動で切替 える制御を提案する. 提案システムを用いて作業対象物と高剛性環境が接触（衝突）した時には, 操作者とロボッ 卜の運動方向と, 外部環境から受ける反力の方向が反対向きになる物理現象を利用し, 検出される力覚情報と位 置偏差情報の正負が逆転する性質を接触判別に用いた.

簡単のため， $\mathrm{x}$ 軸方向について考える．まず， $\alpha=0$ 以外（インピーダンス制御以外）の低干渉化制御が実現 されていて外部環境と接触していない場合（ $\mathrm{x}$ 軸方向への運動が継続している場合）には，力覚情報 $F_{H x}$ と位置 偏差情報 $\Delta p_{x}$ は同一方向に検出される. 作業対象物に力を加えて運動が生じると, 同時に同方向に位置偏差が生 じるためである．接触が発生した瞬間には，位置偏差が生じた状態で，外部環境からの反力によって運動方向と は反対向きの力が検出される.このように，力覚情報 $F_{H x}$ と位置偏差情報 $\Delta p_{x}$ の積の正負に基づいて，正の場合 は非接触，負の場合は接触が発生した状態にあると判断することが可能となる.

本研究では，非接触の場合には，下記の条件(i)または(ii)の制御パラメータを用い，接触が発生した場合には， 条件(iii)または(iv)の制御パラメータを用いて制御を行う。 
(i) $F_{H x} \times \Delta p_{x} \geq 0$ かつ $\left|\Delta p_{x}\right| \geq 2 \mathrm{~mm}$ の場合: $\alpha_{x}=0.5, D_{R x}=76 \mathrm{Ns} / \mathrm{m}$, 力伝達量 $10 \mathrm{~N}$

(ii) $F_{H x} \times \Delta p_{x} \geq 0$ かつ $\left|\Delta p_{x}\right|<2 \mathrm{~mm}$ の場合: $\alpha_{x}=0.5, D_{R x}=200 \mathrm{Ns} / \mathrm{m}$, 力伝達量 $2 \mathrm{~N}$

(iii) $F_{H x} \times \Delta p_{x}<0$ かつ $\left|\Delta p_{x}\right| \geq 2 \mathrm{~mm}$ の場合: $\alpha_{x}=0.5, D_{R x}=200 \mathrm{Ns} / \mathrm{m}$, 力伝達量 $2 \mathrm{~N}$

(iv) $F_{H x} \times \Delta p_{x}<0$ かつ $\left|\Delta p_{x}\right|<2 \mathrm{~mm}$ の場合: $\alpha_{x}=1, D_{R x}=200 \mathrm{Ns} / \mathrm{m}$, 力伝達量 $2 \mathrm{~N}$

$F_{H x}, \Delta p_{x}, \alpha_{x}, D_{R x}$ はそれぞれ $\mathrm{x}$ 軸方向の力覚情報 $[\mathrm{N}]$, 位置偏差情報 $[\mathrm{mm}]$, 入力の重み係数, 粘性係数 $[\mathrm{Ns} / \mathrm{m}]$ を表している. なお, 位置偏差情報の絶対值 $\left|\Delta p_{x}\right|$ に関寸る閾值 $2 \mathrm{~mm}$ は, 外部環境と接触した直後に制御パラメー 夕を切替えた際, ロボットの手先速度を十分に減速させ， ロボットの運動を収束させるために必要な距離であり 実験的に求めた值である，y， $\mathrm{z}$ 軸方向もそれぞれの方向に同様の条件で, 制御パラメータおよび力伝達量を自 動で切替える.

なお，上述した自動切り替え法の提案において，実験的に闇值等を求める試行では，次節（5・1 節）に示す口 ボットの制御パラメータ（インピーダンスパラメータ，仮想剛性係数を含む）を用いた。 これらのパラメータに 変更があれば, 再度, 閾值等を求め直す必要がある. また, 力伝達量の設定值である $2 \mathrm{~N}$ については, 調整器の

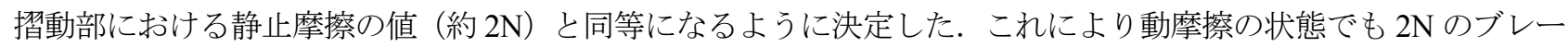
キ力を確保することができている，ロボットと操作者の動特性の非干渉化を実現するためには，本来，力伝達量 が 0N であることが望ましいが，機構の静止摩擦を排除することができなかったことから，現時点では静止状態 において約 $2 \mathrm{~N}$ 程度の相互干渉が生じる低干渉化の実現に止まっている.

\section{5. 協調運搬・はめあい(peg-in-hole)作業実験}

\section{$5 \cdot 1$ 協調運搬・はめあい(peg-in-hole)作業実験}

提案調節器（提案制御則を含む）ならびに自動切替え法の効果を確認するために，高剛性環境との接触および 拘束が生じる作業として，協調運搬・はめあい(peg-in-hole)作業を対象として実験を行う。実験システムを図 10 に示寸. 操作者は提案調節器に取り付けられた peg を操作して holeへ挿入し, その後, peg が hole に挿入された 状態を 5 秒間維持寸る. 実験条件は下記の 4 種であるが，自動切替え法を用いる Case4 を含めたそれぞれの制御 法において, 重み係数 $\alpha$ と力伝達量調節機構のブレーキ力の調節により, 従来のインピーダンス制御において生 じていた接触安定問題が解決できるか，そして協調作業にどのような影響を与えるか（インピーダンス制御との 違いなど）を検証することが本実験の目的である.

Case 1: 力覚情報による制御 $(\alpha=0)$, 力伝達量 10N（通常のインピーダンス制御）

Case 2: 操作者の手先に追従する制御 $(\alpha=1)$, 力伝達量 $0 \mathrm{~N}$

Case 3: 力覚情報による制御と操作者の手先に追従する制御を組み合わせた制御 $(\alpha=0.5)$, 力伝達量 $2 \mathrm{~N}$

Case 4: 自動切替え法を使用した場合

Case 2, Case 3 は，外部環境との接触に伴い，機械的に制御パラメータを可変させる制御則であり，実験開始 時は従来のインピーダンス制御（Case 1）を用い, peg とロボットを力学的に結合させて運搬作業を実施する. そ して, peg が holeに接触した直後に, Case 2, Case 3 の制御パラメータに切り替えて, インピーダンス制御との 違いについて検討する. なお，接触判断は peg と hole の通電状態の有無によって行った（次章にて述べる接触つ ラグ電圧を用いる)。

ロボット手先に与えるインピーダンスパラメータは, $\mathrm{x}, \mathrm{y}, \mathrm{z}$ 軸方向すべてに, 慣性係数 $\boldsymbol{M}_{R}$ を $3 \mathrm{~kg}$, 仮想 剛性係数 $\boldsymbol{K}_{V}$ を $300 \mathrm{~N} / \mathrm{m}$ と設定し, Case 1, Case 2, Case 3 では, 粘性係数 $\boldsymbol{D}_{R}$ を $90 \mathrm{Ns} / \mathrm{m}$ とし, 実験を通して一定 とした. そして, 実験は 3 人の被験者（24 歳の男性健常者）が，各条件において 5 回ずつ，計 20 回の試行を行 う. 被験者は実験施行前にロボット (peg) の操作に対する習熟練習を行っており, 被験者が所望する操作が実現 できるようになっている.

peg と hole の位置関係は図 10 に示すように, peg の先端の初期位置を原点として, $\mathrm{x}$ 軸方向に $100 \mathrm{~mm}, \mathrm{y}$ 軸 方向に-100mm, z 軸方向に $100 \mathrm{~mm}$ の位置に hole 部品を設置し, peg を $80 \mathrm{~mm}$ 差し込むはめあい作業を行う. 実 
験で使用した peg と hole の寸法および寸法公差は, peg 部品が直径 $20_{-0.009}^{0} \mathrm{~mm}$ (寸法公差 h5), hole 部品が直径 $20_{0}^{+0.021} \mathrm{~mm}$ （寸法公差 $\mathrm{H} 7$ ），深さが $80 \mathrm{~mm}$ である.

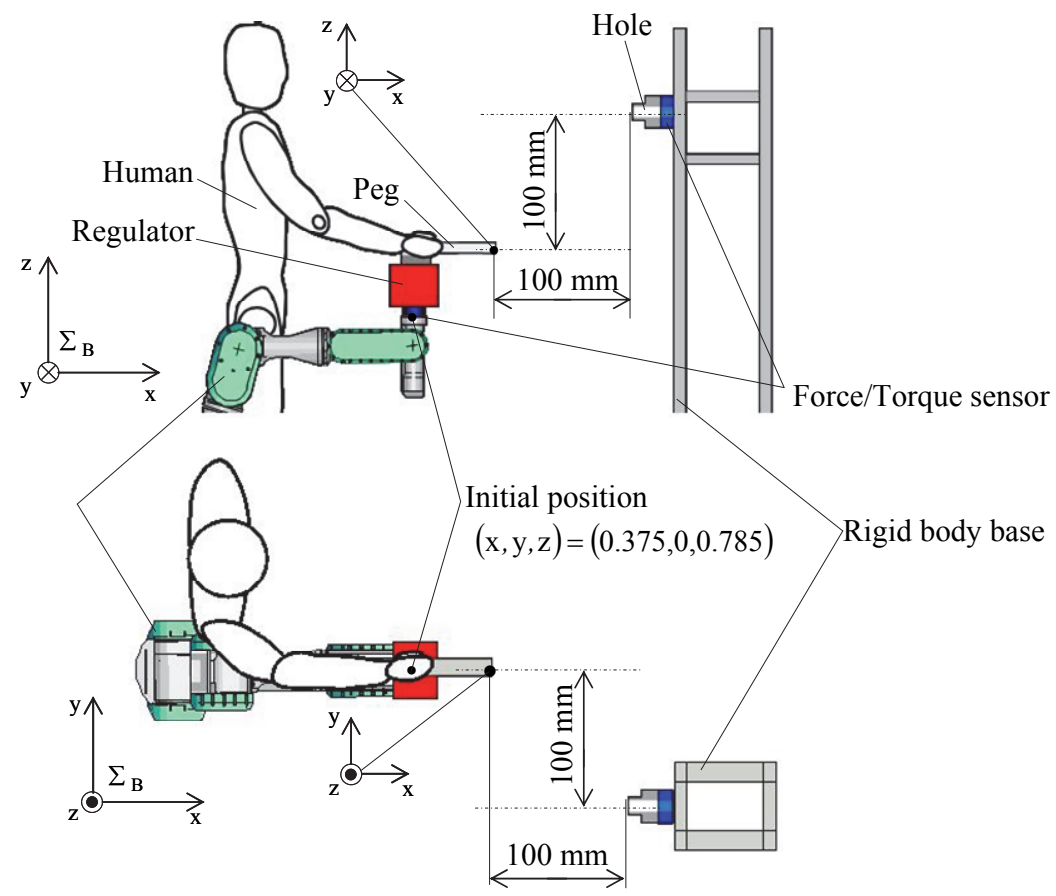

Fig.10 Experimental setup of human-robot cooperative peg-insertion task (peg-in-hole task)

\section{6. 協調運搬 - はめあい(peg-in-hole)作業実験の結果および考察}

図 10，11 に peg-in-hole 実験の結果を示寸. 図 11，12 は, Case 1 から Case 4 の 1 試行おけるロボット手先位置 [m]（ロボット座標系の原点からの值）と接触フラグ電圧[V] (接触状態を判断寸る值), 力覚情報による制御入力 $(1-\alpha) \boldsymbol{F}_{H}[\mathrm{~N}]$ と, 位置偏差情報による仮想力の制御入力 $\alpha \boldsymbol{K}_{V} \Delta \boldsymbol{p}[\mathrm{N}]$ を示す. peg と hole が接触したときに, 接触 フラグ電圧が $1 \mathrm{~V}$, 非接触のときは $0 \mathrm{~V}$ となり, 本研究では, Case 2 から Case 3 において制御法の切替えに利用し た（Case1 において接触状態の維持を表すフラグとして用いる）。図 11，12 は同一の被験者による結果である. 実験は複数の被験者によって行われたが，はめあい作業に必要な時間に若干のばらつきが生じること以外はほぼ 同様の結果が得られている（定量評価については $6 \cdot 5$ 節で述べる）。次節以降，上述のはめあい作業を対象とし て, 各制御則が接触安定問題と協調作業時に与える影響について議論するが，各制御則の制御性能に関する優劣 の議論については今後の課題としたい.

\section{6・1 Case 1（通常のインピーダンス制御）の結果について}

図 11(a), (b), (c)の接触フラグ電圧[V]より, Case 1 は接触状態を維持しての作業ができていないことがわかる. また, 図 12(a), (b), (c)より, 接触作業を行う際, ロボットには大きな反力が加わり, 力覚情報による制御入力 $(1-\alpha) \boldsymbol{F}_{H}$ が大きく振動していることがわかる. さらに，どの被験者も peg を hole 一挿入できなかった．通常の インピーダンス制御では，ロボットと被験者が結合されていることにより，高剛性環境とロボットが接触すると

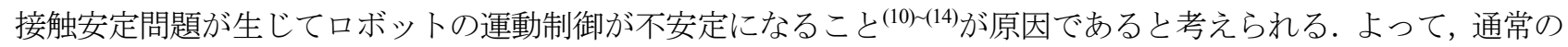
インピーダンス制御では, 接触安定問題が原因となり, 高剛性環境との接触を伴う協調作業を行うことができな い.

\section{6・2 Case 2（入力の重み係数 $\alpha=1$ ，操作者の手先に追従する制御）の結果について}

図 11 (d), (e), (f)の接触フラグ電圧[V]より, Case 2 は接触状態を維持しての作業ができていることがわかる. また, 図 12(d), (e), (f)より, 接触と同時に制御入力が力覚情報による制御入力 $(1-\alpha) \boldsymbol{F}_{H}$ から位置偏差情報によ る仮想力 $\alpha \boldsymbol{K}_{V} \Delta \boldsymbol{p}$ に切替わっており, 挿入状態を維持している時には制御入力が収束していることがわかる. Case 
2 の場合, 重み係数 $\alpha$ を 0 から 1 に切替えることで, peg とロボットとの動特性の干渉が消失し， ロボットが高 剛性環境と接触してもその影響を受けなくなり, 接触安定問題が生じることなく, 接触を伴う協調作業が実現で きた.

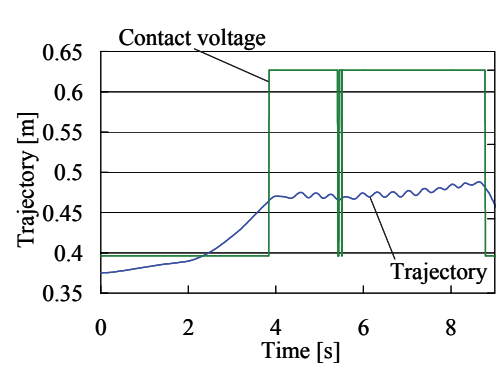

(a) Case 1 (x-axis)

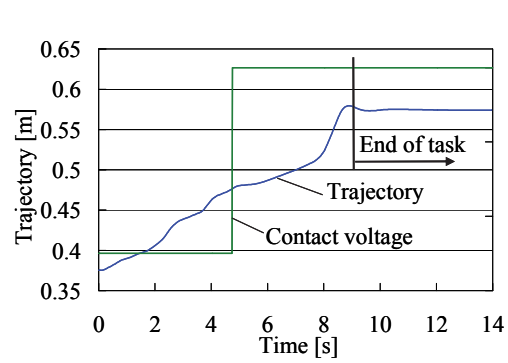

(d) Case 2 (x-axis)

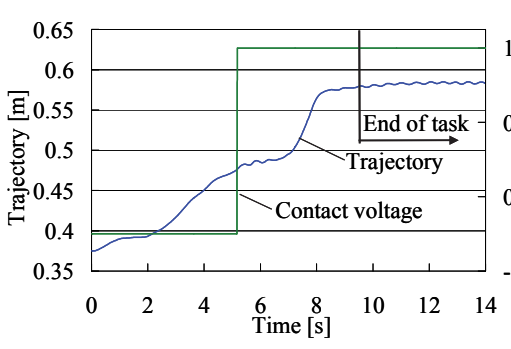

(g) Case 3 (x-axis)

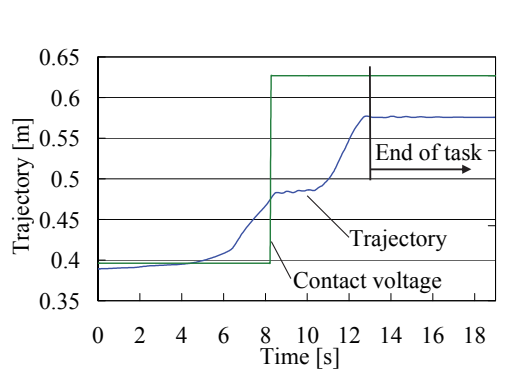

(j) Case 4 (x-axis)

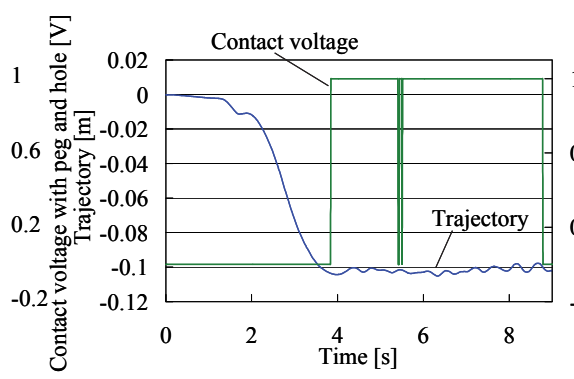

(b) Case 1 (y-axis)

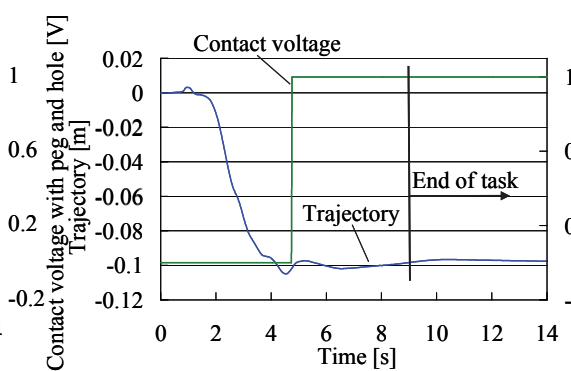

(e) Case 2 (y-axis)

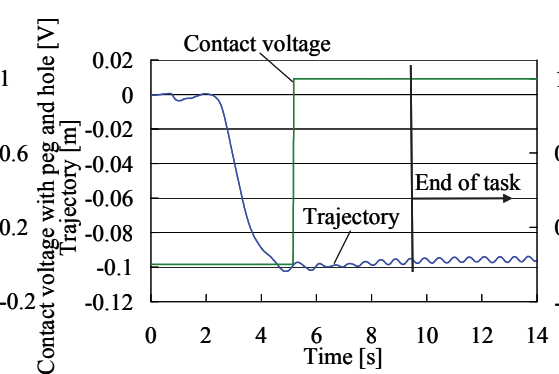

(h) Case 3 (y-axis)

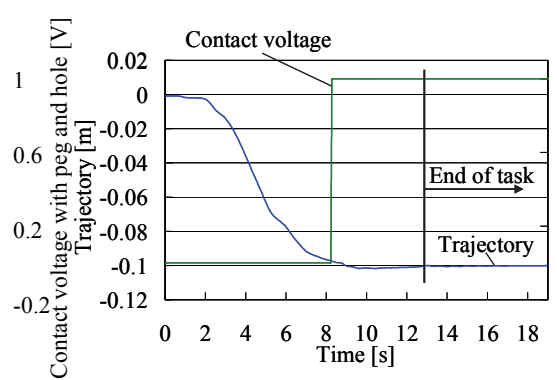

(k) Case 4 (y-axis)

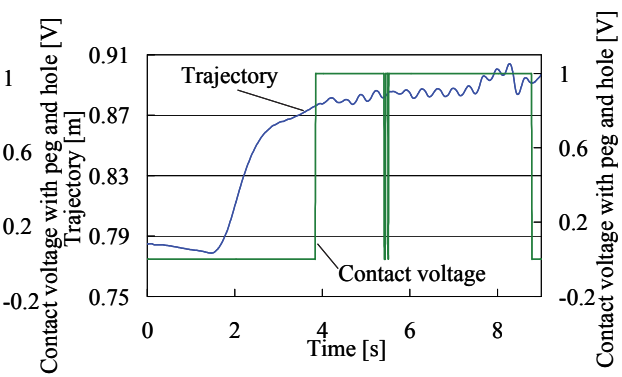

(c) Case 1 (z-axis)

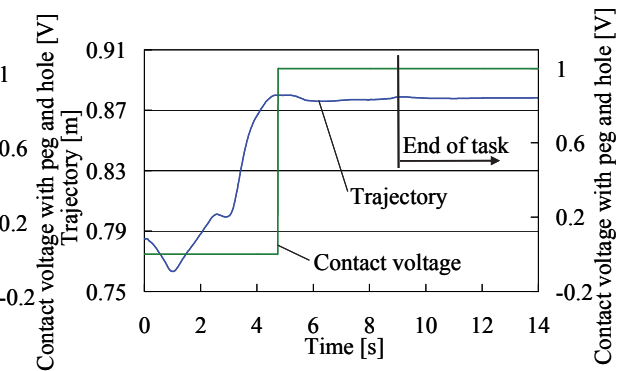

(f) Case 2 (z-axis)

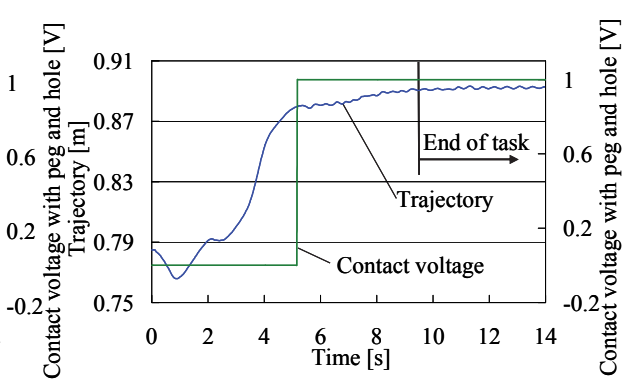

(i) Case 3 (z-axis)

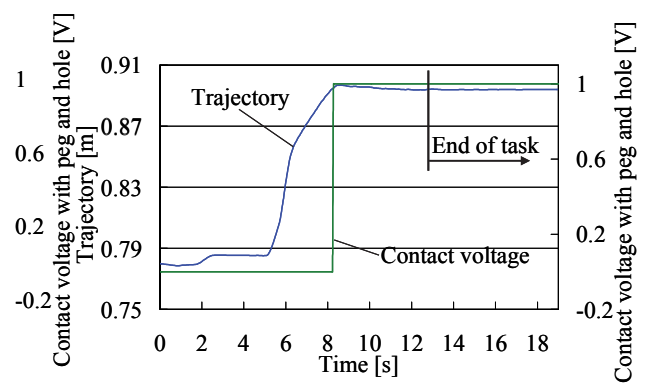

(l) Case 4 (z-axis)

Fig.11 Experimental results of trajectory of robot and contact voltage with peg and hole

被験者の主観的評価によれば，Case2 の制御則では，peg と hole が接触した瞬間から，従来のインピーダンス 制御（Case1）では困難であった外部環境の認識（例えば外部環境の岡性值や動特性を感覚的に認識できるなど） が可能になったとの意見を得ることができ，自らの経験や勘に基づいて直感的に作業を遂行できたとの感想が得 られた。インピーダンス制御であれば，ロボットの運動に慣性，粘性，剛性などの動特性（インピーダンス特性） を付与していることから，操作者はこれらのパラメータからなる動特性に基づく運動を強いられるが，非干渉化 制御下においては, インピーダンス特性が機構的に切り離されるため, 操作者は外部環境の動特性に応じた運動 を実現することが可能になったと考えられる. 
上述の感想は外部環境とロボットの運動との非干涉化（低干渉化）が実現できたことを表しており，peg と hole が持つ固有の動特性に従う作業が可能になったことを示している. これは非干渉化制御の効果の一つであり, 操 作者の直感的な作業の手助けとなったと考えられる.

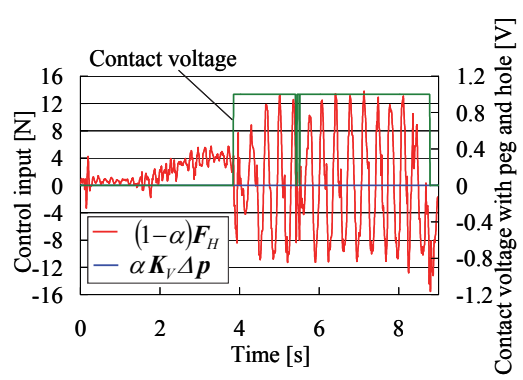

(a) Case 1 (x-axis)

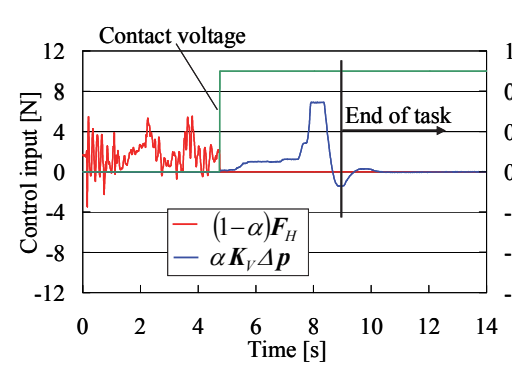

(d) Case 2 (x-axis)

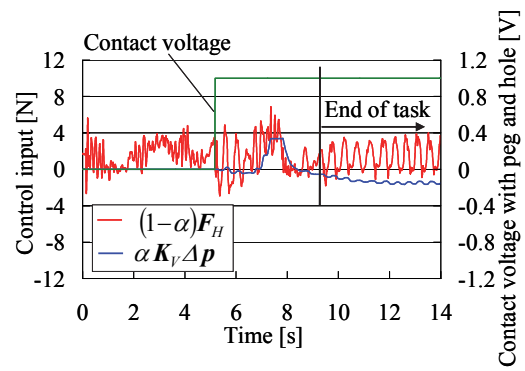

(g) Case 3 (x-axis)

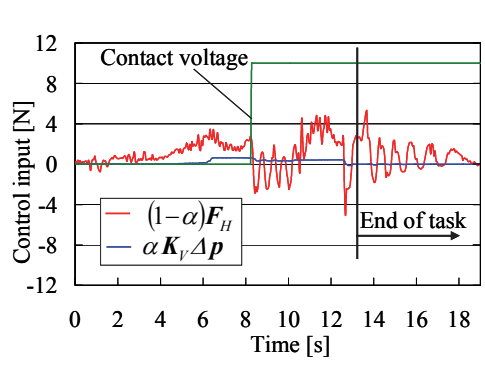

(j) Case 4 (x-axis)

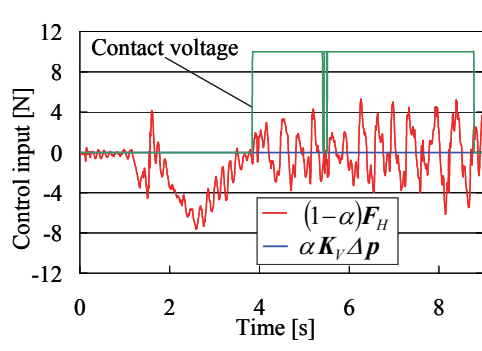

(b) Case 1 (y-axis)

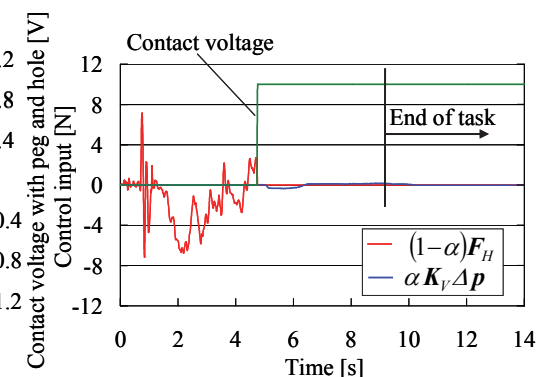

(e) Case 2 (y-axis)
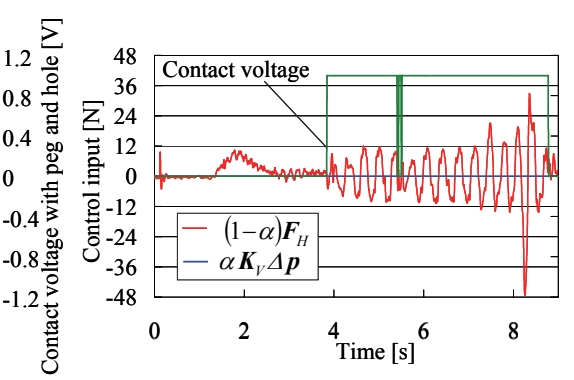

(c) Case 1 (z-axis)

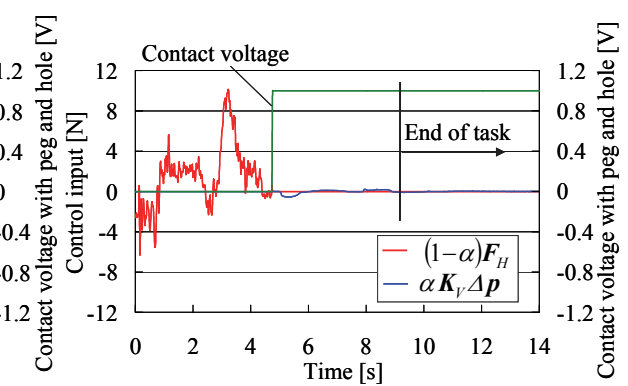

(f) Case 2 (z-axis)

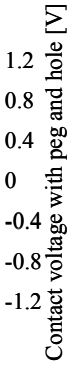




\section{6・3 Case 3（入力の重み係数 $\alpha=0.5 ）$ の結果について}

図 11 (g), (h), (i)の接触フラグ電圧[V] より，Case 3 では接触状態を維持しながら作業を遂行していることがわ かる. しかし，挿入作業が終了し，挿入状態を維持している時に， ロボット手先がわずかに振動する現象が生じ ている. 図 12 (g), (h), (i)において, 制御入力 $(1-\alpha) \boldsymbol{F}_{H}$ の振動が見られ, この入力によりロボット手先の振動が生 じていると考えられる．ロボット手先の位置データの振幅值を確かめるために，扦入状態維持中のロボット手先 の位置データに関する FFT（高速フーリエ変換）処理を行い，得られたパワースペクトルを使用して振幅スペク トルを作成した。 その結果を図13(a)に示す.

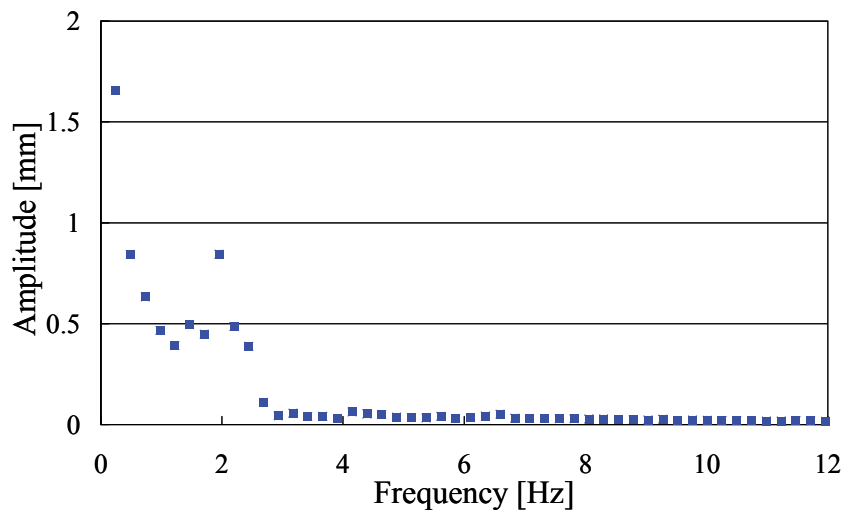

(a) Case 3

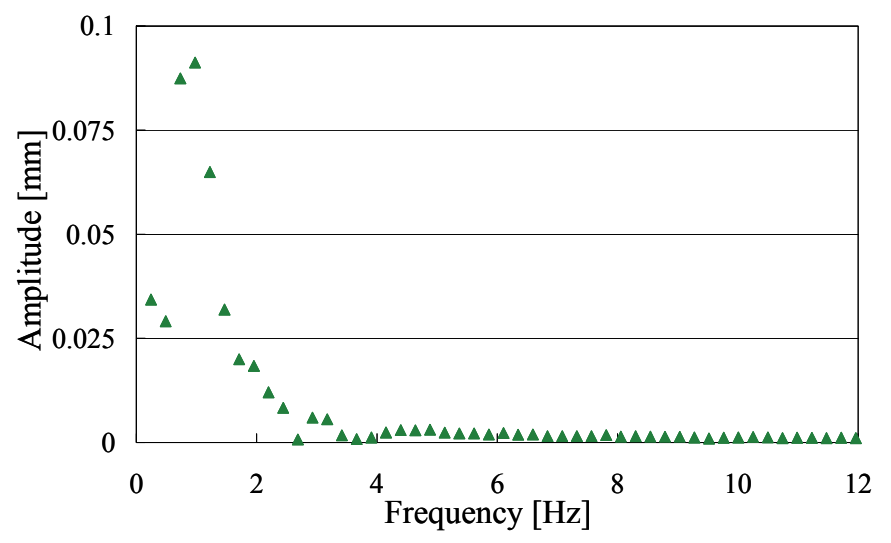

(b) Case 4

Fig.13 Amplitude spectrum of trajectory of robot in a constraint state

図 13(a)より, 最大で $1.6 \mathrm{~mm}$ 程度の振幅を持つ振動成分が確認できた. 制御入力の重み係数 $\alpha$ を 0.5 , 力伝達量 を $2 \mathrm{~N}$ に設定することで，外部環境とロボットの間に力学的相互力が生じたことにより，高剛性環境の影響を受 けてロボットが振動したと考えられる，しかし，ロボット手先は振動しているものの，発散する兆候は確認でき

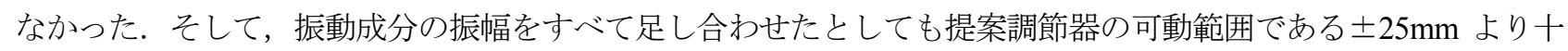
分に小さいことから，制御の安定性を損なうものではないと判断した.

また，Case 2 ではロボットと操作者の力学的相互作用力は消失するが，Case 3 においては被験者とロボットの 力学的相互作用力が生じている状態で高剛性環境との接触作業を実現できるため, ロボットによるパワーアシス 卜効果などの利点を残したまま協調作業を行うことができる.

被験者の主観的評価では, Case3 の制御則においても, Case2 と同様に外部環境の動特性を認識することは可能 であるものの, 設定した $2 \mathrm{~N}$ ほどの干渉化制御の影響によってロボットの運動に付与しているインピーダンス特 性（慣性，粘性）の影響を若干受けているとの感想が得られた。重み係数 $\alpha$ の設定にもよるが，協調作業におい てインピーダンス特性の影響を残すことで, 仮想的な動特性に基づくアシスト（設定する慣性を小さくするなど） が可能になり，適用する対象作業に応じて，適宜，パワーアシスト効果を利用することができる.

以上の議論より, 提案調節器は, 高剛性環境との接触・拘束を伴う協調作業に効果的であるといえる. 本研究 では提案調整器の運動を並進 3 自由度に限定しているが，適用可能な作業例としては，はめあい(peg-in-hole)作業 の他に, 高剛性部材の接触を伴う作業（金属部品の組立てなど）や，作業者の技能の発現が必要な精緻な作業が 挙げられる．特に，非干渉化制御の効果によって，作業者が外部環境の動特性を明確に認識できるようになるこ とから，作業者の経験や勘に基づく直感的な作業が行いやすくなると予想できる.

\section{6・4 Case 4（自動切替え法を用いた制御）の結果について}

図 11(j), (k), (l)の接触フラグ電圧[V] より, 自動切替え法を用いた Case 4 でも, 接触状態を維持しての作業が できていることがわかる. また, 挿入作業終了後の挙動についても, ロボット手先の動きに振動は生じておらず, 安定しているように見える. 挿入状態維持中のロボット手先の位置データに関する FFT 処理を行った結果を図 13(b)に示す. 自動切替え法を用いた場合には, ロボット手先の振動成分は最大でも約 $0.1 \mathrm{~mm}$ という小さい振幅で あることがわかった. Case4 の制御則では，Case3 とほぼ同じパラメータ設定を行っているが，一部の条件におい 
て重み係数 $\alpha$ を 0 にしていること，また，粘性係数を $200 \mathrm{Ns} / \mathrm{m}$ にしているため，振動が収束していると考えられ る. 被験者の主観的評価については，Case4 においても，Case3 とほぼ同じ感想が得られている．しかし，Case3 の場合よりも振動が小さいため，システムの安定状態に関しては Case2 の制御則に近い状態であると言える.

以上より, 自動切替え法により高剛性環境との接触を判別し, 制御パラメータおよび力伝達量を切替えること で，ロボットの運動制御を安定下で実施できることが分かった.

次に，自動切替え法を用いた場合の制御入力の変化を調べる. 図 12(j), (k), (l)より, y 軸方向を除いて, 高剛 性環境と接触中の制御入力は，力覚情報による制御入力が主であることがわかる. 力覚情報と位置偏差情報の比 率を調べるために, 接触開始から挿入作業が完了するまでの力覚情報による制御入力 $(1-\alpha) \boldsymbol{F}_{H}$ と位置偏差情報に よる制御入力 $\alpha \boldsymbol{K}_{V} \Delta \boldsymbol{p}$ の積分值を求めた，そして，制御入力全体の積分值を 100 として，それぞれの制御入力の 積分值の比率を図 14 (Case 2, Case 3, Case 4) に示す.

図 14 より，自動切替え法を用いた Case 4 では，他の条件の制御より力覚情報による制御入力 $(1-\alpha) \boldsymbol{F}_{H}$ が大き な割合を占めていることがわかる（ただしy軸方向を除く）。また，この傾向は今回行った全試行に現れた傾向で ある．これは，高剛性環境との接触中にも関わらず，ロボットの動きが不安定になることなく，従来のインピー ダンス制御に近い運動制御が実現されたことを意味している。これらの結果より，被験者とロボットとの力学的 相互作用を維持したまま（ロボットによるパワーアシスト効果などの利点を残したまま），高剛性環境との接触を 伴う協調作業が可能であることを明らかにした。

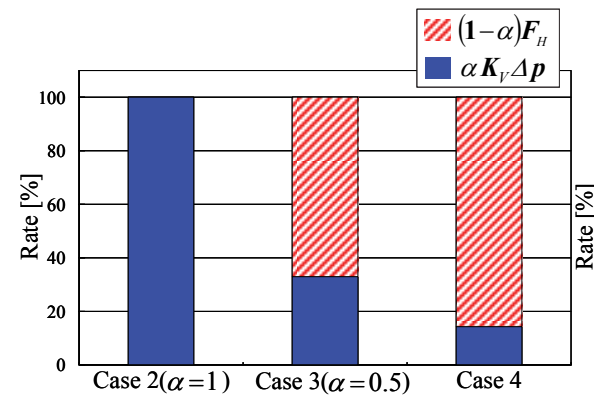

(a) $\mathrm{x}$-axis

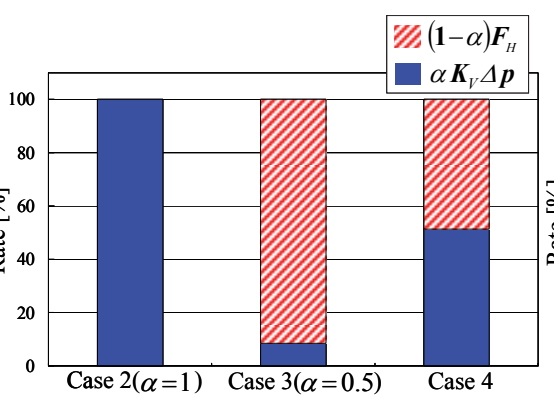

(b) y-axis

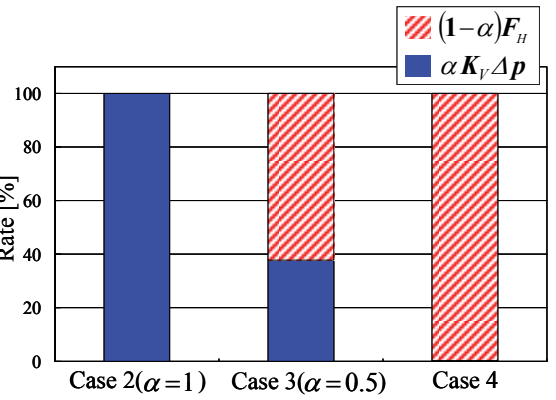

(c) z-axis

Fig.14 Rate of the input forces

なお，y軸方向については，挿入作業を行う $\mathrm{x}$ 軸方向や重力の影響がある $\mathrm{z}$ 軸方向とは違い，ロボットの位置 決めが高剛性環境との接触前に完了していることから, 接触開始時には大きな操作をする必要がなく, 制御入力 の比率の傾向が他軸と異なるものになったと考えられる.

以上より，自動切替え法は高剛性環境との接触・拘束時にも，従来のインピーダンス制御に近い運動制御を実 現できるため，高剛性環境との接触・拘束を伴う人とロボットの協調作業に効果的であったといえる.

\section{$6 \cdot 5$ 実験結果に関する定量評価について}

表 1，2 に, Case2 から Case4 に関する挿入作業に要した平均作業時間, 挿入作業中にロボットの手先位置で計 測された力の絶対值の平均值と標準偏差を示寸. 実験結果の定量評価のため, 被験者間ごとの挿入作業時間 (peg と hole の接触直後から挿入終了までの時間）および挿入作業時間中に peg 挿入方向に生じる力に関する分散分析 を行ったところ, 被験者間, Case 間, すべての組み合わせにおいて有意差は認められなかった（有意水準 $5 \%$ ). この結果から，Case 2 の作業時間についてはばらつきが大きい試行があるものの，いずれの被験者，Caseにおい てもほぼ同様の作業を遂行できていることがわかった．よって，Case2 から Case4のいずれの制御則を用いても 同様の結果が得られることがわかり, それぞれの制御則の間にはそれほど大きな違いがないといえる.あるいは, 対象となる作業において，操作者となる人間の調整能力により同様の結果に収まっていると考えれば，それぞれ の制御則は人間が調整可能な範囲内の違いに留まっていると推測できる. 
Table 1 Average task time of the peg-insertion task

\begin{tabular}{|c|c|r|r|}
\hline Case no. & Subject & $\begin{array}{r}\text { Average } \\
\text { time [s] }\end{array}$ & $\begin{array}{r}\text { Standard } \\
\text { deviation }\end{array}$ \\
\hline \hline \multirow{3}{*}{ Case2 } & $\mathrm{A}$ & 5.6 & 2.5 \\
\cline { 2 - 4 } & $\mathrm{B}$ & 5.8 & 1.4 \\
\cline { 2 - 4 } & $\mathrm{C}$ & 4.8 & 0.8 \\
\hline \multirow{4}{*}{ Case3 } & $\mathrm{A}$ & 4.3 & 0.5 \\
\cline { 2 - 4 } & $\mathrm{B}$ & 4.6 & 0.6 \\
\cline { 2 - 4 } & $\mathrm{C}$ & 4.0 & 0.7 \\
\hline \multirow{4}{*}{ Case4 } & $\mathrm{A}$ & 3.7 & 0.8 \\
\cline { 2 - 4 } & $\mathrm{B}$ & 4.0 & 0.7 \\
\cline { 2 - 4 } & $\mathrm{C}$ & 4.7 & 0.6 \\
\hline
\end{tabular}

Table 2 Average force of the peg-insertion task (x-axis)

\begin{tabular}{|c|c|r|r|}
\hline Case no. & Subject & $\begin{array}{c}\text { Average } \\
\text { force [N] }\end{array}$ & $\begin{array}{r}\text { Standard } \\
\text { deviation }\end{array}$ \\
\hline \hline \multirow{3}{*}{ Case2 } & $\mathrm{A}$ & 5.4 & 0.7 \\
\cline { 2 - 4 } & $\mathrm{B}$ & 3.5 & 0.4 \\
\cline { 2 - 4 } & $\mathrm{C}$ & 4.1 & 0.2 \\
\hline \multirow{4}{*}{ Case3 } & $\mathrm{A}$ & 4.0 & 0.6 \\
\cline { 2 - 4 } & $\mathrm{B}$ & 3.8 & 0.2 \\
\cline { 2 - 4 } & $\mathrm{C}$ & 3.7 & 0.2 \\
\hline \multirow{4}{*}{ Case4 } & $\mathrm{A}$ & 4.7 & 0.6 \\
\cline { 2 - 4 } & $\mathrm{B}$ & 3.9 & 1.1 \\
\cline { 2 - 4 } & $\mathrm{C}$ & 3.6 & 0.8 \\
\hline
\end{tabular}

\section{7. 結語}

本論文では，ロボットと操作者の動特性の干渉具合を調節し，低干渉化（もしくは非干渉化）させる動特性調 節器の開発を行った。 そして，高剛性環境と接触・拘束を伴う協調作業においても安定した制御を可能とするロ ボットの運動制御則を提案した。また，人間とロボットが力学的に協調して peg-in-hole 作業を行うことで，提案 システムと自動切替え法の有効性を示した.

今後の課題としては，提案調節器および運動制御システムの回転運動方向への拡張などが挙げられる.

謝辞

なお，本研究の一部は日本学術振興会 科学研究費補助金 基盤研究（B）（課題番号:21360120）ならびに, 基盤研究（C）（課題番号:24560312）の援助を受けた。ここに記し謝意を表する.

\section{文献}

（1）小菅一弘，藤澤佳生，福田敏男，“仮想ツールダイナミクスに基づくマン・マシン系の制御”，日本機械学会論文集 C 編，Vol. 60, No. 572 (1994), pp. 1337-1343.

（2）池浦良淳，“人間とロボットによる協調作業”，システム／制御／情報，Vol. 44, No. 12 (2000), pp. 682-687.

(3) 原進, 山田陽滋, “サーボ搬送制御とインピーダンス制御のなめらかな切り換えによる台車の位置決め:覚センサ レス制御の実現”，日本機械学会論文集 C 編，Vol.73，No. 730 (2007), pp. 1618-1624.

（4）池浦良淳, 加藤寛之, 野口真平, 水谷一樹, 中村久, 本田朋寛, “接触操作を考慮した産業用パワーアシスト装置 のインピーダンス制御”，日本機械学会論文集 C 編，Vol. 72, No. 714 (2006), pp. 214-221.

(5) Kikuuwe, R., and Fujimoto, H., "Proxy-Based Sliding Mode Control for Accurate and Safe Position Control", IEEE International Conference on Robotics and Automation (2006), pp. 25-30.

(6) Al-Jarrah, O. M., and Zheng, Y.F., “Arm-Manipulator Coordination for Load Sharing Using Variable Compliance Control”, IEEE International Conference on Robotics and Automation (1997), pp. 895-900.

(7) 榎本敦子, 松本義雄, 杉本浩一, “マクロマイクロ機構のインピーダンス制御（作業モデルに基づくモデルベース 制御の統一的手法)”，日本機械学会論文集 C 編，Vol. 66, No. 646 (2000), pp. 1849-1856.

(8) Kazerooni, H., "Human Power Extender: An Example of Human-Machine Interaction via the Transfer of Power and Information Signals”, International Workshop on Advanced Motion Control, (1998), pp. 565-572.

（9）山田陽滋，鴻巣仁司，森園哲也，梅谷陽二，“自動車組み立て工程における搭載作業のためのスキルアシストの提 案”，日本機械学会論文集 C 編, Vol. 68, No. 666 (2002), pp. 161-168.

(10) 榊泰輔, 舘暲, “サーボ系をベースとしたインピーダンス制御おける接触不安定性の改善方法”, 日本ロボット学会 誌, Vol. 13, No. 5 (1995), pp. 659-665. 
(11) Whiney, D.E., "Quasi-Static Assembly of Compliantly Supported Rigid Parts”, Mesurement and Control, Transactions of the ASME, Vol. 104, No. 1 (1982), pp. 65-77.

(12) Surdilovic, D., "Contact Stability Issues in Position Based Impedance Control: Theory and Experiments", IEEE International Conference on Robotics and Automation, Vol. 2 (1996), pp. 1675-1680.

(13) Hogan, N., "On the stability of manipulators performing contact tasks", IEEE Journal of Robotics and Automation, Vol. 4, No. 6 (1988), pp. 677-686.

(14) 榊泰輔, 舘暲, “インピーダンス制御の接触不安定性についての一考察”, 日本ロボット学会誌, vol. 12, No. 3 (1994), pp. 489-496.

(15) 井上康之, 舘暲, “マスタスレーブ・マニピュレータのインピーダンス制御の一方法”, 日本ロボット学会誌, Vol. 10, No. 4 (1992), pp. 490-500.

(16) 武居直行, 野畑茂広, 藤本英雄, “安定した接触を実現するアドミッタンス制御手法”, 日本ロボット学会誌, Vol. 26, No. 6 (2008), pp. 635-642.

(17) Portillo-Velez, R.J., Rodriguez-Angeles, A., and Cruz-Villar, C.A., “An optimal admittance approach for physical human-robot interaction", IEEE International Conference on Electrical Engineering Computing Science and Automatic Control (2011) pp. 1-6.

(18) 山田泰之, 森田寿郎, “摇動スライダクランク機構を用いた機械的自重補償装置”, 日本機械学会論文集，Vol. 76, No. 767 (2010), pp. 1797-1803.

(19) 森田寿郎，“自重補償機構の設計原理と動作支援技術への応用”，バイオメカニズム学会誌，Vol. 30, No. 4 (2006), pp. 200-204.

(20) Morita, T., Kuribara, F., Shiozawa, Y., and SUGANO, S., “A Novel Mechanism Design for Gravity Compensation in Three Dimensional Space”, IEEE International Conference on Advanced Intelligent Mechatronics (2003), pp. 20-40. 